\title{
Effect of the addition of resistant starch in sausage with fat reduction on the physicochemical and sensory properties
}

\author{
Mariana de Souza Leite GARCIA-SANTOS ${ }^{1}$, Flaviana Sales CONCEIÇÃO ${ }^{1}$, Flávia VILLAS BOAS ${ }^{1}$, \\ Bruna Maria SALOTTI DE SOUZA ${ }^{1}$, Andrea Carla da Silva BARRETTO ${ }^{1 \star}$ (D)
}

\begin{abstract}
Sausage is one of the meat products most consumed in Brazil, although the incorporation of fat is necessary for its elaboration, influencing its technological and sensory characteristics and its caloric value. The aim of this study was to evaluate the addition of resistant starch as a fat substitute in sausage on physicochemical properties and sensory acceptance. The analyses performed were the centesimal composition, emulsion stability, instrumental colour, texture profile analysis and sensorial acceptance. The resistant starch was evaluated for thermal properties, demonstrating that it required a high temperature for gelatinization, indicating that there was probably no gelatinisation of the starch in the cooking of the sausages. There was a significant difference between the treatments $T_{1}$ and $T_{2}$ with partial fat reduction and caloric value reduction. The study showed that the partial fat reduction positively influenced the reduction of caloric value, emulsion stability, colour parameters and texture profile analysis. All treatments were well accepted by the consumers. The incorporation of resistant starch in sausages did not influence the centesimal composition, texture profile analysis and sensory analysis, showing it to be a promising ingredient in the making of healthier meat products.
\end{abstract}

Keywords: sausage; resistant starch; fat substitute.

Practical Application: The use of new technologies in the food industry aims to develop new formulations and healthier products for the consumer. In this way, the partial reduction of fat and the resistant starch addition in the preparation of emulsified meat products presents a viable alternative for the production of sausages, contributing to the reduction of calories, acting positively in the manufacturing process and its sensory acceptance.

\section{Introduction}

Sausage is a popular meat product in Brazil with a per capita consumption of $10 \mathrm{~kg} /$ inhabitant (Almeida, 2015) and it is notable for its sensory characteristics, practicality and speed in preparation (Park et al., 2012; Cabral et al., 2014). Sausage is obtained from meat emulsion of one or more animal species with some added ingredients. It can be embedded with natural or artificial wrapping or by extrusion process and subjected to a suitable thermal process, having the maximum fat value of $30 \%$ and the minimum protein requirement of $12 \%$, as legally permitted (Brasil, 2000).

In Brazil, the fat concentration in sausages can influence the consumption of this meat product (Weiss et al., 2010) because the consumers are in search of healthier and more functional food (Jiménez-Colmenero et al., 2010; Hygreeva et al., 2014; Kilıç \& Özer, 2017). Furthermore, high fat consumption has been associated with cardiovascular diseases, obesity, cancer and hypertension, among other illnesses (Mapiye et al., 2012; Hygreeva et al., 2014).

The development of emulsified products with fat substitution or reduction has been studied as one way of meeting such demand, with the incorporation of ingredients to reduce calories to influence the functional properties of the final product (Yang et al., 2001; Ritzoulis et al., 2010; Schmiele et al., 2015;
Zhao et al., 2018; Abbasi et al., 2019). The use of new ingredients as fat substitutes helps with water retention capacity, improves fat functionality, maintains the acceptance of sensory attributes such as appearance, odour, flavour and texture parameters. They also contribute to the challenge of making products that are less caloric, have less fat and have healthier ingredients (Choe et al., 2013; Méndez-Zamora et al., 2015; Zhao et al., 2018; Abbasi et al., 2019).

Several studies have shown the possibility of replacing fat with dietary fibre in meat products with good sensory acceptance (Huang et al., 2011; Grizotto et al., 2012; Schmiele et al., 2015; Talukder, 2015; Barretto et al., 2015; Borrajo et al., 2016; Carvalho et al., 2017; Bis-Souza et al., 2018; Zhao et al., 2018; Abbasi et al., 2019), increasing the intake of this component in the diet. These ingredients can contribute giving technological benefits in meat products in order to improve their nutritional and sensory characteristics (Méndez-Zamora et al., 2015; Paglarini et al., 2018).

The application of soluble and insoluble dietary fibres has been studied both individually and in combination with other ingredients in formulations of emulsified meat products for fat reduction (Ktari et al., 2014; Barretto et al., 2015; MéndezZamora et al., 2015; Borrajo et al., 2016; Zhao et al., 2018; 
Abbasi et al., 2019). The use of resistant starch in emulsified meat products may represent an alternative to help with fat reduction, since it behaves similarly to dietary fibre and is not absorbed in the intestine of healthy individuals (Englyst et al., 1993; Roberfroid, 2007; Viuda-Martos et al., 2010; Peng \& Yao, 2017) and does not supply glucose to the body. It can reach the colon and be fermented by intestinal microbiota bacteria, producing short chain fatty acids and other organic acids (Fuentes-Zaragoza et al., 2010; Haenen et al., 2013). A number of studies have shown the positive effects of resistant starch in cases of obesity (Bodinham et al., 2010), cardiovascular disease (Morita et al., 2005), diabetes (Zhou et al., 2014) and colon cancer (Yin \& Zhao, 2017; Panebianco et al., 2017; Cray et al., 2017).

The commercially available resistant starch is tasteless, white in colour, it presents high gelatinisation temperatures, has water binding capacity and the ability to replace functional characteristics of fat in meat products (Biswas et al., 2011). Thus, the sensory characteristics of products with resistant starch added can be better when compared to those of traditionally high fibre products (Sajilata et al., 2006) or other carbohydrates.

The present study aimed to evaluate the effect of resistant starch application in sausages with partial replacement of fat on the physicochemical and sensory properties.

\section{Materials and methods}

\subsection{Material}

\section{Raw materials}

The ingredients were supplied and the sausage treatments produced at the New Max Industrial's pilot plant located in the city of Americana, SP, Brazil. The resistant starch (type 3) incorporated in the treatments was donated by Ingredion, located in Westchester, Illinois, USA.

\section{Sausage processing}

The sausages were produced at the New Max Industrial pilot plant. The meat raw materials (beef, bacon and mechanically deboned chicken meat) were refrigerated at $-4{ }^{\circ} \mathrm{C}$ and ground in a MEW $6133 \mathrm{~mm}$ grinder (Mado, Dornhan Germany). The MDCM was cut with an SL bandsaw (Metalúrgica Siemsen, Brusque, Brazil) and ground in a $6 \mathrm{~mm}$ grinder. All ingredients were pre-weighed for preparation of the treatments with the formulae described in Table 1.

Table 1. Different formulations of sausage treatments.

\begin{tabular}{lccc}
\hline \multicolumn{1}{c}{ Ingredients } & \multicolumn{1}{c}{$\mathrm{T}_{0}^{*}$} & \multicolumn{1}{c}{$\mathrm{T}_{1}^{*}$} & $\mathrm{~T}_{2}^{*}$ \\
\hline Beef (\%) & 38.0 & 38.0 & 38.0 \\
Mechanically deboned chicken meat (\%) & 27.3 & 27.3 & 27.3 \\
Cure salt (\%) & 0.2 & 0.2 & 0.2 \\
New Mix condiment (\%) & 1.3 & 1.3 & 1.3 \\
Refined salt (\%) & 1.4 & 1.4 & 1.4 \\
Pork back fat (\%) & 15.0 & 11.25 & 7.5 \\
Water and Ice (\%) & 15.0 & 15.75 & 19.5 \\
Cassava starch (\%) & 2.0 & 1.0 & 1.0 \\
Ingredion ${ }^{\mathrm{T}}$ Resistant Starch (\%) & 0.0 & 4.0 & 4.0 \\
\hline
\end{tabular}

${ }^{*} \mathrm{~T}_{0}$ : treatment without resistant starch addition; $\mathrm{T}_{1}$ : treatment with $25 \%$ reduction of pork back fat and the addition of $4 \%$ resistant starch; $\mathrm{T}_{2}$ : treatment with $50 \%$ reduction of pork back fat and the addition of $4 \%$ resistant starch.
For all treatments, the following were added: $38 \%$ of beef, $27.3 \%$ of mechanically deboned poultry meat, $0.2 \%$ of curing salt ( $94 \%$ salt, $6 \%$ sodium nitrite) and $1.3 \%$ of New Max sausage mixed spices and $1.4 \%$ of salt.

All the ingredients for the treatments were added to an MTK 662 stainless steel cutter (Mado, Dornhan, Germany) with a capacity of $10 \mathrm{~kg}$ until a homogeneous batter was obtained, with a temperature control of $12^{\circ} \mathrm{C}$, in order to maintain the batter at an ideal temperature for the sausage processing.

The batter was transferred to an EM 20 hydraulic sausage filling machine, (Mainca, Barcelona, Spain) and embedded in cellulose gut casing with a $25 \mathrm{~mm}$ gauge and twisted into $12 \mathrm{~cm}$ long links. After that, the links were placed on skewers to be cooked in a Unimatic 2200 steam oven (Eller, Brazil) until the internal temperature of the product reached $72{ }^{\circ} \mathrm{C}$. The treatments were cooled in a cold water shower for a period of 5 minutes in order to stop cooking inside the product $\left(40^{\circ} \mathrm{C}\right)$. They were then stored in $4{ }^{\circ} \mathrm{C}$ refrigeration chambers. The treatments were submitted to manual dewatering for the removal of the cellulose casing and packed in polyethylene nylon vacuum bags at a temperature of $4 \pm 1{ }^{\circ} \mathrm{C}$ until the physicochemical and sensory analyses which were performed in triplicate at the Department of Engineering and Food Science of the Institute of Biosciences, Languages and Exact Sciences, UNESP.

In order to verify the repeatability of the process, triplicates of the processing were performed for each treatment.

\subsection{Methods}

\section{Resistant starch: thermal properties}

The gelatinisation temperatures and enthalpy changes of the resistant starch were determined using a Pyris1 differential scanning calorimeter (DSC) (Perkin Elmer, USA) as described by Franco et al. (2002).

\section{Physicochemical characteristics of sausages}

The moisture, protein, lipid and ash contents of the three sausage treatments were determined in triplicate at room temperature $\left(25^{\circ} \mathrm{C}\right)$ following the Association of Official Analytical Chemists' methodology (Association of Official Analytical Chemists, 2005). The moisture was determined in direct oven drying at $105{ }^{\circ} \mathrm{C}$. For the protein content, the Kjeldahl method ( $\mathrm{N}$ x 6.25) was used. The lipid content was determined according to Bligh \& Dyer (1959). For the ash content, the samples were incinerated and the carbohydrate content was calculated by the difference. The results of all analysis were expressed as percentages. The caloric value of the sausage treatments was determined using Chemin \& Mura's (2008) calculation, where the content of the protein nutrient, carbohydrates and lipids corresponds to $4 \mathrm{kcal}, 4 \mathrm{kcal}$ and $9 \mathrm{kcal}$ respectively.

The $\mathrm{pH}$ was evaluated using a PG1800 $\mathrm{pH}$ meter (Gehaka, São Paulo, Brazil) with a drill electrode inserted directly into the sample at room temperature $\left(25^{\circ} \mathrm{C}\right)$. 


\section{Instrumental colour analysis}

The instrumental colour analysis was determined using a Color Flex45/0 spectrophotometer (Hunterlab, USA), the universal software version 4.10 with the D65 illuminating and $10^{\circ}$ observer configurations. The absolute values of the rectangular coordinates $\mathrm{L}^{*}$ (Luminosity), $\mathrm{a}^{*}$ (Intensity of red) and $\mathrm{b}^{*}$ (Intensity of yellow) allowed the calculation of the cylindrical coordinates. Twelve sausages cut in lengthways format at room temperature $\left(25^{\circ} \mathrm{C}\right)$ were analyzed for each treatment.

\section{Emulsion stability}

The emulsion stability was determined according to the method described by Jiménez-Colmenero et al. (1995) with some modifications where approximately $50 \mathrm{~g}$ of batter were placed in sealed tubes and centrifuged for 5 minutes at $2{ }^{\circ} \mathrm{C}$, after which they were submitted to heat at $40^{\circ} \mathrm{C}$ for 15 minutes and after that, the heat was increased to $70^{\circ} \mathrm{C}$ for 20 minutes. The exudate liquid was measured for the "emulsion break" evaluation and the results were expressed as a percentage (\%).

\section{Texture profile analysis}

The texture profile analysis (TPA) of the sausages was carried out in a TA.XT.Plus/50 texturometer (Stable Micro Systems, Godalming, UK) previously calibrated with a standard weight of $5 \mathrm{~kg}$. The sausages were pre-cut in $20 \mathrm{~mm}$ lengths in order to be inserted into the equipment. A $25 \mathrm{~mm}$ aluminium probe with a speed of $5 \mathrm{~mm} / \mathrm{s}$ and a $13 \mathrm{~mm}$ platform distance was used, which compressed $50 \%$ of the sample axially in two consecutive cycles, a total of totalling 11 samples for each treatment were tested, at a temperature of $25^{\circ} \mathrm{C}$, according to Bourne et al. (1978). The data collection and the construction of the TPA curves were performed by the Texture Exponent 32 program (Stable Micro Systems, Godalming, UK). The parameters determined were hardness, cohesiveness, springiness and chewiness. The hardness was defined by the peak force during the first compression cycle. Cohesiveness was calculated as the ratio between the second and first peak areas (A2/A1). The springiness was defined between the peak and the time from the beginning of the first area to the first peak (b/a). The chewiness was obtained by multiplying hardness $\times$ springiness $\times$ cohesiveness.

\subsection{Sensory analysis}

The sensory acceptance test of the sausage treatments was carried out at the Sensory Analysis Laboratory of the Department of Engineering and Food Science at the Institute of Biosciences, Languages and Exact Sciences, UNESP. The study was approved by the Ethics Committee in Research from the same institution with Opinion no 864.959.

Seventy potential sausage consumers were recruited to evaluate the treatments. The sensory analysis was performed the day after the manufacturing process of the sausage treatments. The samples were prepared according to the recommendation of the manufacturers of commercial sausages and were served in circular format with a $3 \mathrm{~cm}$ thickness and presented to consumers in white plastic cups, coded with random three digit numbers, presented in monadic form and in individual cabins illuminated with white light.

The treatments were evaluated as the sensory attributes of appearance, colour, odour, taste and overall acceptance using a structured hedonic scale of nine points ( $1=\mathrm{I}$ highly disliked it, 9=I liked it a lot) and, for purchase intention, a 5 point scale was used $1=$ certainly would not buy; 5 = certainly would buy) (Stone \& Sidel, 2004).

\subsection{Statistical analysis}

The results obtained on physicochemical properties (composition, instrumental color, texture profile analysis) and from the sensorial test were expressed as the mean values and the standard error of the mean. These data were analyzed statistically using mixed model ANOVA analyses and the means were compared using the Tukey test $(p<0.05)$.

All results were submitted to principal component analysis (PCA) to investigate correlations between them. The means of the variable were inserted in columns (dependent variables) and the different treatments of sausages in rows (cases), and the data were standardized before the analysis, applying a correlation matrix without factor rotation. Statistical analyses were performed using Statistic $@$ v. 7.0 (StatSoft, Tulsa, USA).

\section{Results and discussion}

\subsection{Thermal properties}

Table 2 presents the thermal properties of the resistant starch used.

The resistant starch presented a high gelatinisation temperature range showing that there was no gelatinisation of the starch granules in the sausage processing, which would lead to loss of resistance of this starch. Cassava starch is the starch most used in sausage formulations in Brazil, where the gelatinisation temperature for cassava starch is between 67.1 to $70.1{ }^{\circ} \mathrm{C}$ (Gomand et al., 2010). Studies carried out with eight different cassava starch genotypes showed a gelatinisation temperature range between 72.7 and $78.3^{\circ} \mathrm{C}$ (Rolland-Sabaté et al., 2013).

\subsection{Physicochemical characterization}

Table 3 shows the results of the centesimal composition, emulsion stability, instrumental colour and texture profile analysis (TPA) of the different sausage treatments.

The moisture levels between treatments presented a significant difference $(p<0.05)$, where the contents varied between 58.5 and $62.8 \% . \mathrm{T}_{2}$ presented higher moisture value amongst treatments possibly due to the higher amount of water added in the formulation. All treatments have a moisture content within the

Table 2. Resistant starch - thermal properties.

\begin{tabular}{ccccc}
\hline Sample & $\mathrm{T}_{0}^{*}\left({ }^{\circ} \mathrm{C}\right)$ & $\mathrm{T}_{\mathrm{p}}^{*}\left({ }^{\circ} \mathrm{C}\right)$ & $\mathrm{T}_{\mathrm{f}}^{*}\left({ }^{\circ} \mathrm{C}\right)$ & $\Delta \mathrm{H}^{*}(\mathrm{~J} / \mathrm{g})$ \\
\hline $\mathrm{AR}$ & $110.9 \pm 1.0$ & $127.1 \pm 0.6$ & $142.3 \pm 0.1$ & $8.53 \pm 0.2$ \\
\hline${ }^{*} \mathrm{~T}_{\mathrm{o}}$ : initial temperature; $\mathrm{T}$ : peak temperature; $\mathrm{T}_{\mathrm{f}}$ f final temperature; $\Delta \mathrm{H}$ : enthalpy \\
variation. Averages \pm standard deviation. $\mathrm{n}=3$.
\end{tabular}


Table 3. Sausage treatment's centesimal composition, instrumental colour and texture profile analysis.

\begin{tabular}{|c|c|c|c|c|c|}
\hline & $\mathrm{T}_{0}^{*}$ & $\mathrm{~T}_{1}^{*}$ & $\mathrm{~T}_{2}^{*}$ & $\mathrm{p}$ & SEM $^{4}$ \\
\hline \multicolumn{6}{|l|}{ Centesimal composition } \\
\hline Moisture $(\%)^{1}$ & $58.5^{c}$ & $60.9^{b}$ & $62.8^{\mathrm{a}}$ & 0.0000 & 0.6220 \\
\hline Lipids $(\%)^{1}$ & $19.5^{\mathrm{a}}$ & $17.6^{\mathrm{b}}$ & $15.4^{\mathrm{c}}$ & 0.0031 & 0.6403 \\
\hline Protein $(\%)^{1}$ & 12.9 & 11.9 & 12.1 & 0.0469 & 0.1857 \\
\hline $\operatorname{Ash}(\%)^{1}$ & $3.5^{\mathrm{a}}$ & $3.3^{\mathrm{b}}$ & $3.3^{\mathrm{b}}$ & 0.0006 & 0.0343 \\
\hline Carbohydrates (\%) & 4.0 & 8.7 & 6.5 & - & - \\
\hline Calories (kcal/ $100 \mathrm{~g}$ ) & 242.7 & 240.7 & 212.6 & - & - \\
\hline $\mathrm{pH}^{1}$ & $6.10^{c}$ & $6.16^{\mathrm{b}}$ & $6.21^{\mathrm{a}}$ & 0.0007 & 0.0177 \\
\hline Emulsion stability $(\%)^{1}$ & 99.5 & 98.8 & 99.1 & 0.5060 & 0.2309 \\
\hline \multicolumn{6}{|l|}{ Colour parameters } \\
\hline $\mathrm{L}^{\star 2}$ & $51.1^{\mathrm{b}}$ & $54.0^{\mathrm{a}}$ & $50.8^{\mathrm{b}}$ & 0.0000 & 0.2842 \\
\hline$a^{\star 2}$ & $13.3^{\mathrm{a}}$ & $12.4^{\mathrm{b}}$ & $13.2^{\mathrm{a}}$ & 0.0000 & 0.0851 \\
\hline $\mathrm{b}^{* 2}$ & $13.6^{\mathrm{a}}$ & $13.4^{\mathrm{b}}$ & $13.7^{\mathrm{a}}$ & 0.0025 & 0.0346 \\
\hline \multicolumn{6}{|l|}{ Texture profile analysis } \\
\hline Hardness $(\mathrm{N})^{3}$ & $9.7^{\mathrm{ab}}$ & $11.9^{\mathrm{a}}$ & $8.7^{\mathrm{b}}$ & 0.0271 & 0.5081 \\
\hline Cohesiveness $^{3}$ & $0.7^{\mathrm{a}}$ & $0.5^{\mathrm{b}}$ & $0.7^{\mathrm{a}}$ & 0.0002 & 0.0017 \\
\hline Springiness $^{3}(\mathrm{~mm})$ & $0.8^{\mathrm{b}}$ & $0.8^{\mathrm{a}}$ & $0.8^{\mathrm{a}}$ & 0.0012 & 0.0071 \\
\hline Chewiness $(\text { N.mm })^{3}$ & 5.2 & 5.2 & 4.5 & 0.4541 & 0.2547 \\
\hline
\end{tabular}

${ }^{*} \mathrm{~T}_{0}$ : treatment without resistant starch addition; $\mathrm{T}_{1}$ : treatment with $25 \%$ reduction of pork back fat and the addition of $4 \%$ resistant starch; $\mathrm{T}_{2}$ : treatment with $50 \%$ reduction of pork back fat and the addition of $4 \%$ resistant starch. ${ }^{1} \mathrm{n}=3$, Carbohydrate content was calculated by the difference; ${ }^{2} \mathrm{n}=12 ;{ }^{3} \mathrm{n}=11 ;{ }^{4} \mathrm{SEM}$ - Standard error of measurements. Averages with different letters in the same line indicate statistical differences $(p \leq 0.05)$ by the Tukey test.

limit established by the Brazilian legislation - 65\% (Brasil, 2000). A study carried out with the substitution of bacon by wheat fibre in proportions of 10, 15 and 20\% for sausages of the Frankfurter type presented values above those reported in this study, with moisture content between 58.14 and 68.13\% (Choe et al., 2013). Similar values are reported by Méndez-Zamora et al. (2015), who stated that the addition of inulin and pectin fibres in Frankfurter type sausages influenced the increase in moisture due to the water retention capacity of the fibres.

A significant reduction in the percentage of lipids was observed for $\mathrm{T}_{1}(17.6 \%)$ and $\mathrm{T}_{2}(15.4 \%)$ compared to $\mathrm{T}_{0}(19.5 \%)$, showing that the reduction of the addition of back fat by $25 \%$ and $50 \%$ for $\mathrm{T}_{1} \mathrm{e} \mathrm{T}_{2}$, respectively, influenced this result. The results of this work corroborate the study by Choe et al. (2013), stating that the lipid content decreased as the highest percentage (20\%) of wheat fibre was added in Frankfurter type sausages. Thus, it is possible to affirm that the reduction of $25 \%$ of pork back fat in $\mathrm{T}_{1}$ and $50 \%$ in $\mathrm{T}_{2}$ contributed to the decrease in the caloric value of the sausage treatments which were 240.7 and $212.6 \mathrm{kcal} / 100 \mathrm{~g}$ of sausage respectively. Choe et al. (2013) demonstrated that the caloric value of Frankfurter type sausages was influenced by fat reduced and added wheat fibre.

There was no significant difference for the protein content $(p \leq 0.05)$ amongst treatments and values ranged between 11.9 and $12.9 \%$.

The percentage of carbohydrates found in the present study showed values that varied between 4.0 and $8.7 \%$, taking into account the values allowed by the Brazilian legislation
(Brasil, 2000). The presence of resistant starch as a fat substitute increased the carbohydrate content in the treatments, with $\mathrm{T}_{1}$ having the highest carbohydrate value (8.7\%) and considering that cassava starch was not the only source of carbohydrate used in the formulations. According to Daguer et al. (2011), sausage products have added starch used as binders, although these ingredients should be classified as fillers due to their cost reduction in the manufacturing process. They also help in the product's water retention, consequently decreasing the meat concentration of the product.

There was a significant difference for the ash content $(p<0.05)$ between treatments where the contents varied between 3.25 and $3.45 \%$. Similar values of ash content were described by Borrajo et al. (2016) in sausages with added wheat fibre.

The addition of resistant starch in sausages increased $\mathrm{pH}$ values $(p \leq 0.05)$ where the average varied from 6.10 to 6.21 . The addition of resistant starch and the partial reduction of fat in sausage did not influence the emulsion stability, $(p \leq 0.05)$. Possibly the other raw materials used contributed to a positive result in emulsion stability. Choe et al. (2013) reported improve yield by adding three different levels of wheat fibre $(10,15$ and $20 \%)$ in Frankfurter type sausages. A proportional inverse relationship with cooking loss was observed, explained by the high water and fat retention capacity present in the fibres.

The partial reduction of fat was approximately $10 \%$ and $21 \%$ for $T_{1}$ and $T_{2}$, respectively. According to the Brazilian legislation, sausages made with beef, pork or poultry must have the following chemical composition: maximum moisture of $65 \%$, minimum protein of $12 \%$ and maximum lipid of $30 \%$ (Brasil, 2000).

Regarding the luminosity values $\left(\mathrm{L}^{*}\right)$, these vary in the scale, from 0 to 100 , indicating the light reflectance. The higher the values, the lighter the colour of the sausages (Ramos \& Gomide, 2017). The values of luminosity $\left(\mathrm{L}^{\star}\right)$ in the treatments varied between 50.8 and 54.0. $\mathrm{T}_{1}$ was the lightest value possibly due to the raw material used. $T_{2}$ presented a value similar to $\mathrm{T}_{0}$ showing that the resistant starch did not influence this parameter. The colour parameters of sausages with added resistant starch were also determined by Sarteshnizi et al. (2015) who obtained values for luminosity $\left(L^{*}\right)$ of 47.42 when $2 \%$ of resistant starch was added.

For the parameter $\mathrm{a}^{*}$ (red and green intensity) and for parameter $b^{*}$ (yellow and blue intensity) (Table 3 ) there was a difference between the treatments but the resistant starch did not compromise this result. Méndez-Zamora et al. (2015) presented similar values to the ones in this study for parameters $\mathrm{a}^{*}$ and $\mathrm{b}^{*}$ and affirms that the addition of pectin and inulin in sausages influence the red and yellow tonality.

From the TPA (Table 3) it was possible to calculate the texture parameters for each of the sausage treatments. There was no difference for chewiness $(p \leq 0.05)$ among the treatments. However, for hardness, cohesiveness and springiness the treatments differed from each other $(p \leq 0.05)$. $\mathrm{T}_{1}$ was the treatment with the highest average for hardness (11.87). In the studies carried out on the elaboration of sausages with added wheat fibre, the 
authors report that the value of hardness increased due to the presence of $20 \%$ added wheat fibre (Choe et al., 2013).

For the cohesiveness parameter, $\mathrm{T}_{1}$ presented the lowest value for the parameter (0.53). However, the values for this parameter are all low which characterizes that all the treatments are of easy compression and rupture in the teeth. This decrease in hardness and increased cohesiveness was also observed by Sarteshnizi et al. (2015) with the addition of resistant starch in sausages. Values below those found in this study were determined by Choe et al. (2013), with values ranging from 0.27 to 0.34 for cohesiveness in sausages with the addition of wheat fibre and reduction of back fat.

In the springiness parameter, treatments $\mathrm{T}_{1}$ and $\mathrm{T}_{2}$ had different values $(p \leq 0.05)$ from $\mathrm{T}_{0}$ as the latter was the sample with the highest springiness. Méndez-Zamora et al. (2015) reports the positive effect on springiness with the addition of inulin and pectin in Frankfurter type sausages, and attributed the increase in the springiness in sausages to the addition of dietary fibres and their functional capacity as a substitute for fat by water retention.

Table 4. Sensory acceptance for sausages treatments.

\begin{tabular}{llllcc}
\hline \multicolumn{1}{c}{ Attributes } & $\mathrm{T}_{0}{ }^{*}$ & $\mathrm{~T}_{1}{ }^{*}$ & $\mathrm{~T}_{2}{ }^{*}$ & $\mathrm{p}$ & SEM \\
\hline Appearance & 6.7 & 6.7 & 6.7 & 0.000 & 0.1035 \\
Colour & 6.7 & 6.4 & 6.6 & 0.000 & 0.1041 \\
Odour & 7.2 & 7.1 & 6.9 & 0.000 & 0.0896 \\
Flavour & 7.3 & 6.8 & 6.8 & 0.000 & 0.1166 \\
Texture & 7.4 & 6.8 & 7.0 & 0.000 & 0.1030 \\
Overall acceptance & 7.2 & 6.8 & 6.9 & 0.000 & 0.0966 \\
\hline
\end{tabular}

${ }^{*} \mathrm{~T}_{0}$ : treatment without resistant starch addition; $\mathrm{T}_{1}$ : treatment with $25 \%$ reduction of pork back fat and addition of $4 \%$ resistant starch; $\mathrm{T}_{2}$ : treatment with $50 \%$ reduction of pork back fat and addition of $4 \%$ of resistant starch. SEM - Standard error of measurements. There was no significant statistical difference $(p>0.05)$.

\subsection{Sensory analysis}

The appearance, colour, odour, flavour, texture and overall acceptance attributes of the sausages treatments are presented in Table 4.

The results of the sensory acceptance did not present any significant difference among the treatments $(p \leq 0.05)$ for the appearance, colour, flavour, texture, aroma and overall acceptance attributes. Thus, all treatments were well accepted by consumers, contributing to the reduction of fat in sausages. Grizotto et al. (2012) carried out a study with the addition of two types of okara flour in Frankfurter type sausages with partial (1.5\%) and total (4.0\%) replacement of texturized soy protein and concluded that the addition of okara flour did not influence sensory acceptance. In their research, Choe et al. (2013) worked with Frankfurter sausages substituting bacon with wheat fibre in proportions of 10,15 and $20 \%$, and all the samples were well accepted.

\subsection{Principal component analysis}

The principal components analysis (PCA) showed that the first main component explained $62.31 \%$ of the data variation and the second main component explained $37.69 \%$ (Figure 1), where the two eigenvectors were both important in the explanation of the variance of the data, totalling $100 \%$ of the variation observed for sausage treatments and evaluated parameters.

The location of each sausage treatment suggests what the evaluated parameters were and presented greater content or characterization of the sausages of this study. The first main component was explained by the presence of $\mathrm{T}_{2}$, characterized by the parameters of carbohydrates, moisture and $\mathrm{pH}$ positively correlated. For $\mathrm{T}_{1}$, hardness and luminosity $\left(\mathrm{L}^{*}\right)$ parameters were positive. For $\mathrm{T}_{0}$, protein and ashes parameters characterized this
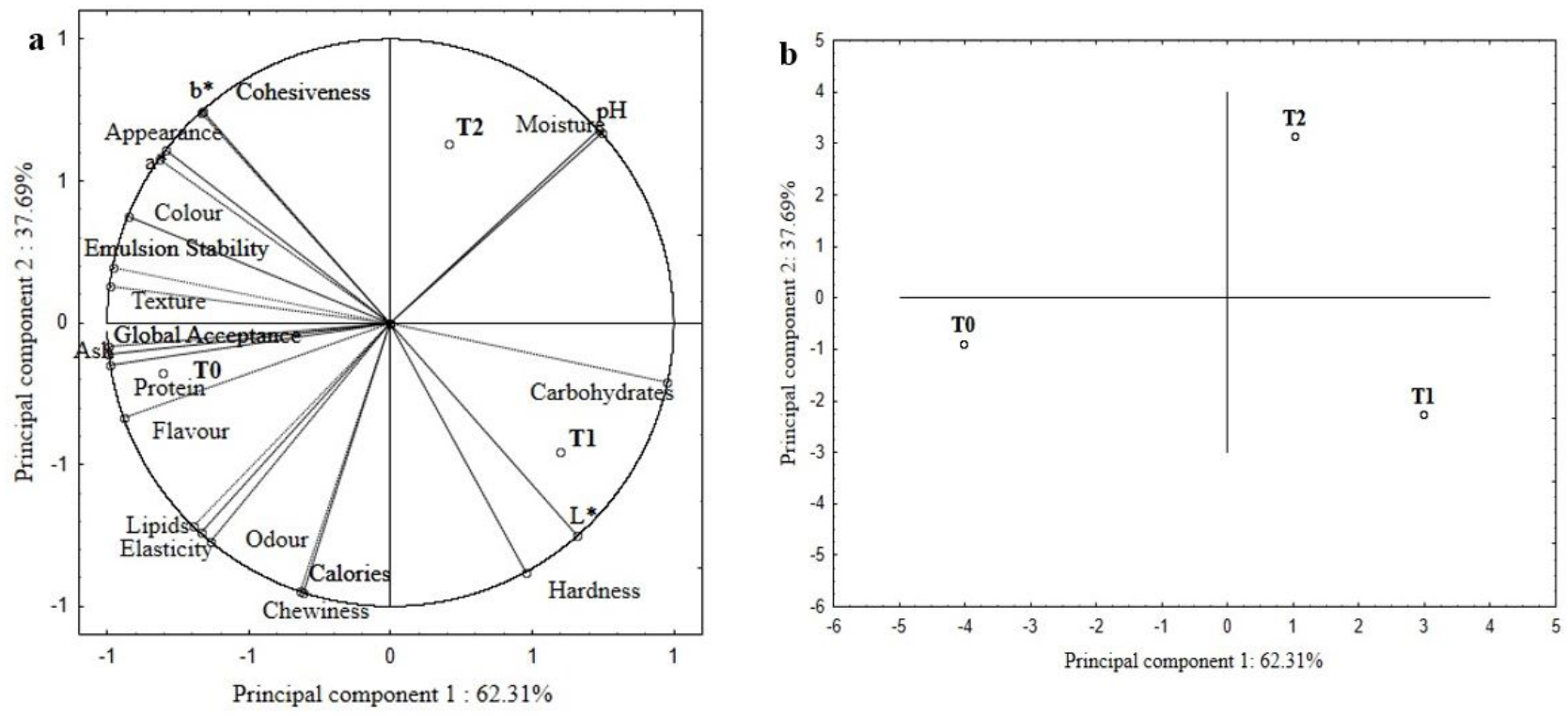

Figure 1. Principal components analysis among physical, sensory, texture profile analysis. (a) variables projection; (b) samples projection. $\mathrm{T}_{0}$ : treatment without resistant starch addition; $\mathrm{T}_{1}$ : treatment with $25 \%$ reduction of pork back fat and addition of $4 \%$ resistant starch; $\mathrm{T}_{2}$ : treatment with $50 \%$ reduction of pork back fat and addition of $4 \%$ of resistant starch. 
treatment, besides being represented in the component by the overall acceptance. Therefore, the principal component analysis (PCA), corroborates the data presented in Tables 3 and 4.

\section{Conclusion}

The addition of resistant starch as a fat substitute in sausages did not influence the centesimal composition, texture profile analysis and sensory analysis, indicating it to be a promising ingredient in the making of healthier meat products.

\section{Acknowledgements}

The authors are grateful to the company New Max Industrial and the FAPERP (Foundation for Support to Research and Extension of São José do Rio Preto) (Processo n 007/2019).

\section{References}

Abbasi, E., Amini Sarteshnizi, R., Ahmadi Gavlighi, H., Nikoo, M., Azizi, M. H., \& Sadeghinejad, N. (2019). Effect of partial replacement of fat with added water and tragacanth gum (Astragalus gossypinus and Astragalus compactus) on the physicochemical, texture, oxidative stability, and sensory property of reduced fat emulsion type sausage. Meat Science, 147, 135-143. http://dx.doi.org/10.1016/j. meatsci.2018.09.007. PMid:30243231.

Almeida, A. L. (2015). A desconstrução de um vilão: entrevista cedida à Thaís Ito. Revista Nacional da Carne, (457), 50-55. Retrieved from https://issuu.com/btsinforma/docs/revista_digital_457_carne

Association of Official Analytical Chemists - AOAC. (2005). Official methods of Analysis of the Association of Official Analytical Chemists (18th ed.). Maryland: AOAC.

Barretto, A. C. S., Pacheco, M. T. B., \& Pollonio, M. A. R. (2015). Effect of the addition of wheat fiber and partial pork back fat on the chemical composition, texture and sensory property of low-fat bologna sausage containing inulin and oat fiber. Food Science and Technology, 35(1), 100-107. http://dx.doi.org/10.1590/1678-457X.6496.

Bis-Souza, C. V., Henck, J. M. M., \& Barretto, A. C. S. (2018). Performance of low-fat beef burger with added soluble and insoluble dietary fibers. Food Science and Technology, 38(3), 522-529. http://dx.doi. org/10.1590/fst.09217.

Biswas, A. K., Kumar, V., Bhosle, S., Sahoo, J., \& Chatli, M. K. (2011). Dietary fibers as functional ingredients in meat products and their role in human health. International Journal of Livestock Production, 2(4), 45-54.

Bligh, E. G., \& Dyer, W. J. (1959). A rapid method of total lipid extraction and purification. Canadian Journal of Biochemistry and Physiology, 37(8), 911-917. http://dx.doi.org/10.1139/o59-099. PMid:13671378.

Bodinham, C. L., Frost, G. S., \& Robertson, M. D. (2010). Acute ingestion of resistant starch reduces food intake in healthy adults. British Journal of Nutrition, 103(6), 917-922. http://dx.doi.org/10.1017/ S0007114509992534. PMid:19857367.

Borrajo, K. H. T., de Lima, C. G., \& Trindade, M. A. (2016). Saciedade subjetiva, aceitação sensorial e aspectos tecnológicos de salsicha com adição de fibra de trigo. Brazilian Journal of Food Technology, 19(e2016008), 1-8.

Bourne, M. C., Kenny, J. F., \& Barnard, J. (1978). Computer-assisted readout of data from texture profile analysis curves. Journal of Texture Studies, 9(4), 481-494. http://dx.doi.org/10.1111/j.1745-4603.1978. tb01219.x.
Brasil, Ministério da Agricultura, Pecuária e Abastecimento. (2000, April 5). Aprova os Regulamentos Técnicos de identidade e qualidade de carne mecanicamente separada, de mortadela, de lingüiça e de salsicha (Instrução Normativa no ${ }^{\circ}$, de 31 de março de 2000). Diário Oficial [da] República Federativa do Brasil.

Cabral, C. C., Conte-Júnior, C. A., Silva, J. T., \& Paschoalin, V. M. F. (2014). Salmonella spp. contamination in fresh pork and chicken sausages marketed in Niterói and Rio de Janeiro, Brazil. Journal of Consumer Protection and Food Safety, 9(3), 243-249. http://dx.doi. org/10.1007/s00003-014-0901-0.

Carvalho, G. R., Milani, T. M. G., Trinca, N. R. R., Nagai, L. Y., \& Barretto, A. C. S. (2017). Textured soy protein, collagen and maltodextrin as extenders to improve the physicochemical and sensory properties of beef burger. Food Science and Technology, 37(1, Suppl 1), 10-16. http://dx.doi.org/10.1590/1678-457x.31916.

Chemin, S. M. S. S., \& Mura, J. D. P. (2008). Tratado de alimentação, nutrição e dietoterapia (2. ed.). São Paulo: Roca.

Choe, J. H., Kim, H. Y., Lee, J. M., Kim, Y. J., \& Kim, C. J. (2013). Quality of frankfurter-type sausages with added pig skin and wheat fiber mixture as fat replacers. Meat Science, 93(4), 849-854. http://dx.doi. org/10.1016/j.meatsci.2012.11.054. PMid:23313971.

Cray, N., Zhao, Y., Fang, Y., Liu, P., Pollak, L., Duvick, S., Birt, D. F., \& Whitley, E. M. (2017). Effects of dietary resistant starch on the wnt signaling pathway and preneoplastic cells in the colons of azoxymethane-treated rats. Nutrition and Cancer, 69(4), 632-642. http://dx.doi.org/10.1080/01635581.2017.1299875. PMid:28362171.

Daguer, H., Silva, H. D., Higashiyama, E. T., Zanette, C. M., \& Bersot, L. S. (2011). Qualidade de produtos cárneos fabricados sob inspeção federal no estado do Paraná. Ciência Animal Brasileira, 12(2), 1-3. http://dx.doi.org/10.5216/cab.v12i2.8136.

Englyst, H. N., Quigley, M. E., Hudson, G. J., \& Cummings, J. H. (1993). Determination of dietary fibre as non-starch polysaccharides with gasliquid chromatographic, high-performance liquid chromatographic or spectrophotometric measurement of constituent sugars. 118(5), 582. http://dx.doi.org/10.1039/an9931800582. PMid:7943740.

Franco, C. M. L., Cabral, R. A., \& Tavares, D. Q. (2002). Structural and physicochemical characteristics of lintnerized native and sour cassava starches. Stärke, 54(10), 469-475. http://dx.doi.org/10.1002/1521379X(200210)54:10<469::AID-STAR469>3.0.CO;2-Z.

Fuentes-Zaragoza, E., Riquelme-Navarrete, M. J., Sánchez-Zapata, E., \& Pérez-Álvarez, J. A. (2010). Resistant starch as functional ingredient: a review. Food Research International, 43(4), 931-942. http://dx.doi. org/10.1016/j.foodres.2010.02.004.

Gomand, S. V., Lamberts, L., Derde, L. J., Goesaert, H., Vandeputte, G. E., Goderis, B., Visser, R. G. F., \& Delcour, J. A. (2010). Structural properties and gelatinisation characteristics of potato and cassava starches and mutants thereof. Food Hydrocolloids, 24(4), 307-317. http://dx.doi.org/10.1016/j.foodhyd.2009.10.008.

Grizotto, R. K., Andrade, J. C., Miyagusku, L., \& Yamada, E. A. (2012). Physical, chemical, technological and sensory characteristics of Frankfurter type sausage containing okara flour. Food Science and Technology, 32(3), 538-546. http://dx.doi.org/10.1590/S010120612012005000076.

Haenen, D., Zhang, J., Souza da Silva, C., Bosch, G., van der Meer, I. M., van Arkel, J., van den Borne, J. J., Pérez Gutiérrez, O., Smidt, H., Kemp, B., Müller, M., \& Hooiveld, G. J. (2013). A diet high in resistant starch modulates microbiota composition, SCFA concentrations, and gene expression in pig intestine. The Journal of Nutrition, 143(3), 274-283. http://dx.doi.org/10.3945/jn.112.169672. PMid:23325922.

Huang, S. C., Tsai, Y. F., \& Chen, C. M. (2011). Effects of wheat fiber, oat fiber, and inulin on sensory and physic-chemical properties 
of Chinese-style sausages. Asian-Australasian Journal of Animal Sciences, 24(6), 875-880. http://dx.doi.org/10.5713/ajas.2011.10317.

Hygreeva, D., Pandey, M. C., \& Radhakrishna, K. (2014). Potential applications of plant based derivatives as fat replacers, antioxidants and antimicrobials in fresh and processed meat products. Meat Science, 98(1), 47-57. http://dx.doi.org/10.1016/j.meatsci.2014.04.006. PMid:24845336.

Jiménez-Colmenero, F., Carballo, J., \& Solas, M. T. (1995). The effect of use of freeze-thawed pork on the properties of Bologna sausages with two fat levels. International Journal of Food Science \& Technology, 30(3), 335-345. http://dx.doi.org/10.1111/j.1365-2621.1995.tb01382.x.

Jiménez-Colmenero, F., Cofrades, S., López-López, I., Ruiz-Capillas, C., Pintado, T., \& Solas, M. T. (2010). Technological and sensory characteristics of reduced/low-fat, low-salt frankfurters as affected by the addition of konjac and seaweed. Meat Science, 84(3), 356-363. http://dx.doi.org/10.1016/j.meatsci.2009.09.002. PMid:20374797.

Kılıç, B., \& Özer, C. O. (2017). Effects of replacement of beef fat with interesterified palm kernel oil on the quality characteristics of Turkish dry-fermented sausage. Meat Science, 131, 18-24. http:// dx.doi.org/10.1016/j.meatsci.2017.04.020. PMid:28453979.

Ktari, N., Smaoui, S., Trabelsi, I., Nasri, M., \& Ben Salah, R. (2014). Chemical composition, Techno-functional and sensory properties and effects of three dietary fibers on the quality characteristics of Tunisian beef sausage. Meat Science, 96(1), 521-525. http://dx.doi. org/10.1016/j.meatsci.2013.07.038. PMid:24013695.

Mapiye, C., Aldai, N., Turner, T. D., Aalhus, J. L., Rolland, D. C., Kramer, J. K., \& Dugan, M. E. (2012). The labile lipid fraction of meat: from perceived disease and waste to health and opportunity. Meat Science, 92(3), 210-220. http://dx.doi.org/10.1016/j.meatsci.2012.03.016. PMid:22546816.

Méndez-Zamora, G., García-Macías, J. A., Santellano-Estrada, E., Chávez-Martínez, A., Durán-Meléndez, L. A., Silva-Vázquez, R., \& Quintero-Ramos, A. (2015). Fat reduction in the formulation of frankfurter sausages using inulin and pectin. Food Science and Technology, 35(1), 25-31. http://dx.doi.org/10.1590/1678-457X.6417.

Morita, T., Kasaoka, S., Kiriyama, S., Brown, I. L., \& Topping, D. L. (2005). Comparative effects of acetylated and unmodified highamylose maize starch in rats. Stärke, 57(6), 246-253. http://dx.doi. org/10.1002/star.200400373.

Paglarini, C. S., Furtado, G. F., Biachi, J. P., Vidal, V. A. S., Martini, S., Forte, M. B. S., Cunha, R. L., \& Pollonio, M. A. R. (2018). Functional emulsion gels with potential application in meat products. Journal of Food Engineering, 222, 29-37. http://dx.doi.org/10.1016/j. jfoodeng.2017.10.026.

Panebianco, C., Adamberg, K., Adamberg, S., Saracino, C., Jaagura, M., Kolk, K., di Chio, A. G., Graziano, P., Vilu, R., \& Pazienza, V. (2017). Engineered resistant-starch (ERS) diet shapes colon microbiota profile in parallel with the retardation of tumor growth in in vitro and in vivo pancreatic cancer models. Nutrients, 9(4), 331. http:// dx.doi.org/10.3390/nu9040331. PMid:28346394.

Park, K. S., Choi, Y. S., Kim, H. Y., Kim, H. W., Song, D. H., Hwang, K. E., Choi, S. G., \& Kim, C. J. (2012). Quality characteristics of chicken emulsion sausages with different levels of Makgeolli lees fiber. Han-gug Chugsan Sigpum Hag-hoeji, 32(1), 54-61. http:// dx.doi.org/10.5851/kosfa.2012.32.1.54.

Peng, X., \& Yao, Y. (2017). Carbohydrates as fat replacers. Annual Review of Food Science and Technology, 8(1), 331-351. http://dx.doi. org/10.1146/annurev-food-030216-030034. PMid:28245156.

Ramos, E. M., \& Gomide, L. A. M. (2017). Avaliação da qualidade de carnes: fundamentos e metodologias (2. ed.). In E. M. Ramos \& L.
A. M. Gomide, Avaliação instrumental da cor (cap. 6, pp. 212-253). Viçosa: UFG.

Ritzoulis, C., Petridis, D., Derlikis, E. M., Fytianos, K., \& Asteriou, P. (2010). Utilization of inverse water-in-oil emulsions as fat replacers in frankfurter model sausages: influence of fat emulsion content on the organoleptic and mechanical properties. Journal of Texture Studies, 41(1), 62-74. http://dx.doi.org/10.1111/j.1745-4603.2009.00213.x.

Roberfroid, M. (2007). Prebiotics: the concept revisited. The Journal of Nutrition, 137(3, Suppl 2), 830S-837S. http://dx.doi.org/10.1093/ jn/137.3.830S. PMid:17311983.

Rolland-Sabaté, A., Sanchez, T., Buléon, A., Colonna, P., Ceballos, H., Zhao, S. S., Zhang, P., \& Dufour, D. (2013). Molecular and supramolecular structure of waxy starches developed from cassava (Manihot esculenta Crantz). Carbohydrate Polymers, 92(2), 1451-1462. http:// dx.doi.org/10.1016/j.carbpol.2012.10.048. PMid:23399176.

Sajilata, M. G., Singhal, R. S., \& Kulkarni, P. R. (2006). Resistant starch: a review. Comprehensive Reviews in Food Science and Food Safety, 5(1), 1-17. http://dx.doi.org/10.1111/j.1541-4337.2006.tb00076.x.

Sarteshnizi, R. A., Hosseini, H., Bondarianzadeh, D., Jiménez-Colmenero, F., \& Khaksar, R. (2015). Optimization of prebiotic sausage formulation: effect of using $\beta$-glucan and resistant starch by $\mathrm{D}$-optimal mixture design approach. Lebensmittel-Wissenschaft + Technologie, 62(1), 704-710. http://dx.doi.org/10.1016/j.lwt.2014.05.014.

Schmiele, M., Mascarenhas, M. C. C. N., Barretto, A. C. S., \& Pollonio, M. A. R. (2015). Dietary fiber as fat substitute in emulsified and cooked meat model system. Lebensmittel-Wissenschaft + Technologie, 61(1), 105-111. http://dx.doi.org/10.1016/j.lwt.2014.11.037.

Stone, H., \& Sidel, J. L. (2004). Sensory evaluation practices (3rd ed.). London: Elsevier Academic Press.

Talukder, S. (2015). Effect of dietary fiber on properties and acceptance of meat products: a review. Critical Reviews in Food Science and Nutrition, 55(7), 1005-1011. http://dx.doi.org/10.1080/10408398. 2012.682230. PMid:24915339.

Viuda-Martos, M., Ruiz-Navajas, Y., Fernández-López, J., \& Pérez-Álvarez, J. A. (2010). Effect of added citrus fiber and spice essential oils on quality characteristics and shelf-life of mortadella. Meat Science, 85(3), 568-576. http://dx.doi.org/10.1016/j.meatsci.2010.03.007. PMid:20416839.

Weiss, J., Gibis, M., Schuh, V., \& Salminen, H. (2010). Advances in ingredient and processing systems for meat and meat products. Meat Science, 86(1), 196-213. http://dx.doi.org/10.1016/j.meatsci.2010.05.008. PMid:20619800.

Yang, A., Keeton, J. T., Beilken, S. L., \& Trout, G. R. (2001). Evaluation of some binders and fat substitutes in low-fat Frankfurters. Journal of Food Science, 66(7), 1039-1046. http://dx.doi.org/10.1111/j.1365-2621.2001. tb08232.x.

Yin, D. T., \& Zhao, X. H. (2017). Impact of exogenous strains on in vitro fermentation and anti-colon cancer activities of maize resistant starch and xylo-oligosaccharides. Starch, 69(11), 1-28.

Zhao, Y., Hou, Q., Zhuang, X., Wang, Y., Zhou, G., \& Zhang, W. (2018). Effect of regenerated cellulose fiber on the physicochemical properties and sensory characteristics of fat-reduced emulsified sausage. Lebensmittel-Wissenschaft + Technologie, 97, 157-163. http://dx.doi. org/10.1016/j.lwt.2018.06.053.

Zhou, X. H., Dong, Y., Zhao, Y. S., Xiao, X., Wang, Y., He, Y. Q., \& Liu, Q. Q. (2014). A three generation reproduction study with Sprague-Dawley rats consuming high-amylose transgenic rice. Food and Chemical Toxicology, 74, 20-27. http://dx.doi.org/10.1016/j. fct.2014.08.015. PMid:25194626. 